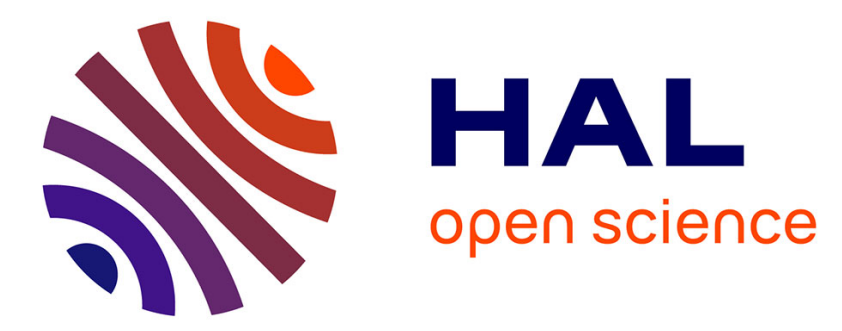

\title{
Recent dynamics of the wet pastures at Oukaimeden plateau (High Atlas mountains, Morroco)
}

S. Alaoui Haroni,, M. Alifriqui, Vincent Simonneaux

\section{To cite this version:}

S. Alaoui Haroni,, M. Alifriqui, Vincent Simonneaux. Recent dynamics of the wet pastures at Oukaimeden plateau (High Atlas mountains, Morroco). Biodiversity and Conservation, 2009, 18 (1), pp.167189. 10.1007/s10531-008-9465-6 . ird-00384686

\section{HAL Id: ird-00384686 \\ https://hal.ird.fr/ird-00384686}

Submitted on 15 May 2009

HAL is a multi-disciplinary open access archive for the deposit and dissemination of scientific research documents, whether they are published or not. The documents may come from teaching and research institutions in France or abroad, or from public or private research centers.
L'archive ouverte pluridisciplinaire HAL, est destinée au dépôt et à la diffusion de documents scientifiques de niveau recherche, publiés ou non, émanant des établissements d'enseignement et de recherche français ou étrangers, des laboratoires publics ou privés. 


\title{
Recent dynamics of the wet pastures at Oukaimeden plateau (High Atlas mountains, Morroco)
}

\author{
S. Alaoui Haroni · M. Alifriqui · V. Simonneaux
}

Received: 27 November 2007/ Accepted: 28 August 2008/Published online: 24 September 2008

(C) Springer Science+Business Media B.V. 2008

\begin{abstract}
Wetlands are a very important universal heritage; in the Moroccan High Atlas mountains the geomorphology and the slopes evolution determine the existence of the numerous projecting ledges of pozzines on plateaus and oozing. This is particularly the case in Oukaimeden site located at $75 \mathrm{~km}$ south of Marrakesh. These wet grasslands have been developed on small surface areas supported by soils water accumulation; and close to the sources and on some banks constitute wetlands of high floristic richness, which makes them very coveted pastures by local populations. These wet pastures are highly sensitive to climatic factors. Recent climatic changes, the anthropic and pastoral pressures and the global environmental changes, affect these zones at the level of their structure (areas, soil characteristics...) and their ecological functions. In the Oukaimeden plateau, the use of aerial photography made it possible to carry out a detailed follow up of the hydraulic adjustments (dam construction in the 1970s) as well as the setting up of new adjustments (tracks, paths, drain channel) on the structure and functioning of these grasslands.
\end{abstract}

Keywords Wet grasslands · Cartography · Dynamic · GIS · Biodiversity · High Atlas mountains · Morocco

\section{Introduction}

All over the world, wetlands are of particular scientific interest, for their great ecological value as ecosystems containing a very characteristic flora and fauna. Particularly in Morocco, this is practically the richest country in wetlands among all the North African countries. Moroccan wetlands are characterized by a highly degree of biodiversity (Hammada et al. 2004).

S. Alaoui Haroni $(\bowtie) \cdot M$. Alifriqui

Equipe Ecologie Végétale, Sol et Environnement, Faculté des Sciences Semlalia, Université Cadi Ayyad, Marrakech, Avenue Prince Moulay Abdallah, BP 2390, Marrakech 40000, Morocco e-mail: alaoui_safia@yahoo.fr

V. Simonneaux

Projet SudMed, IRD, Faculté des Sciences Semlalia, Université Cadi Ayyad, Marrakech, Morocco 
In the High Atlas mountains, the wetlands subject of this study are present at the altitudes ranging between 2,500 and 3,000 m, and occupy depressions and projecting ledges where water, fine materials (sand, clay) and humic matter accumulate (Quézel 1957; Gauquelin 1988). They are mountainous vegetal formations named pozzines; this term was introduced into the scientific literature by the botanist Briquet in 1910 to indicate wetland vegetal formations of the High Corsican mountains.

Those pozzines occupy the projecting ledges which accumulate fine materials that allow a good retention of water precipitations and snow melt; these elements come from the framing slopes colonized by xeric thornyshrubs. They are the only summit vegetal groupings where recognition of sometimes complex soil is possible, but often without discernible strata (Gauquelin 1988). Therefore, these pozzines were described and recognized as being a specialized grouping related to the local climatic and edaphic conditions (Galland 1988).

The vegetation of the wet grasslands consists of an endemic flora, particularly rich in alpine and boreal plants. In this location, these wetlands which have been dominated by centuries-old pastoral exploitation, are still very coveted for the pasture and undergo a particular traditional management (Berque 1955). Considering their vulnerability, permanent or intermittent wetlands are very affected by climatic changes (Harris et al. 2006), by the anthropic and pastoral pressure (He et al. 2005). Indeed, because of their strict water determinism and soil, the altitudinal wet grasslands are highly affected by the recent climatic changes (Hulme 2005; Harris et al. 2006) and for this reason constitute very good witnesses of the environmental changes that the site undergoes.

\section{Materials and methods}

Geographical situation

The Oukaimeden plateau (W $7^{\circ} 52^{\prime}, \mathrm{N} 31^{\circ} 12^{\prime}$ ) is located at $75 \mathrm{~km}$ south of Marrakesh (Fig. 1); it rises at an altitude of $2,650 \mathrm{~m}$.

\section{Geology}

The site of Oukaimeden belongs to the High siliceous Atlas mountains with an acid eruptive Precambrian substrate comprising Rhyolites and Andesites, is limited to the North by red sandy substrates of Jbel Tizrag, from permotriasic age (Dresch 1941; Quézel 1957).

\section{Climate}

The Oukaimeden site is dominated by the semiarid Mediterranean bioclimate with cold winter variant. Rainfall varies between 400 and $500 \mathrm{~mm} /$ year (Fig. 2). Snowfall is significant between December and March; freezing days are estimated between 82 and 139 days/ year according to years. The temperatures are rather low, the minima average in the coldest month is evaluated at $-2.69^{\circ} \mathrm{C}$ and the average maxima of the hottest month reached $23.5^{\circ} \mathrm{C}$.

Vegetation

The Oukaimeden grasslands flora is remarkable mountainous vegetation, rich in endemic species and supplemented with plants of alpine and boreal origin. It is consist of vegetal 


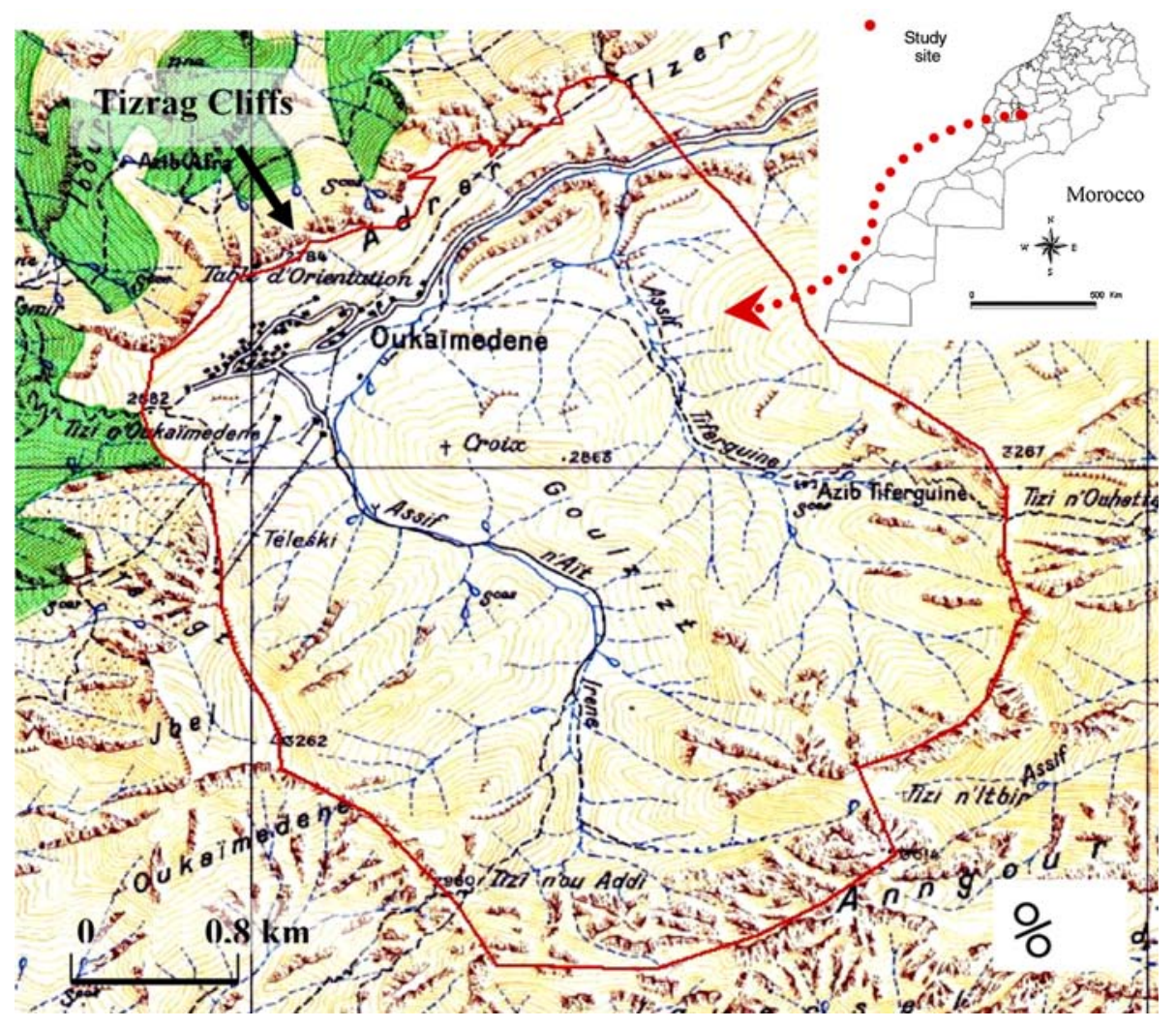

Fig. 1 Map of the Oukaimeden site situation

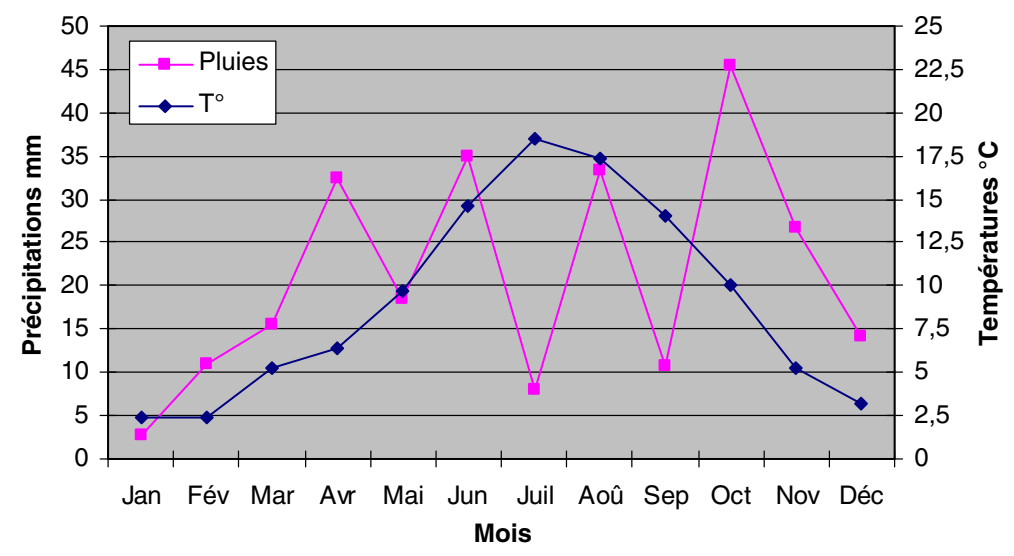

Fig. 2 Ombrothermic diagram (2001-2007) (The climatic data come from the station of the Oukaimeden (2600 m) CAF (Alpine French Club) 
Table 1 Characteristics of the various facies of the Oukaimeden wet grasslands (Gauquelin 1988)

\begin{tabular}{|c|c|c|c|c|}
\hline Facies & Substrate nature & $\begin{array}{l}\text { Humidity } \\
\text { (in the first } 10 \mathrm{~cm} \\
\text { in the soil) }\end{array}$ & Slope & Recovery \\
\hline $\begin{array}{l}\text { Highly wet } \\
\text { grassland }+ \text { pozzine }\end{array}$ & Peaty soil & $100 \%$ & $<5 \%$ & $100 \%$ \\
\hline Wet grasslands & Marly clayey soil & $80 \%$ to $100 \%$ & $<5 \%$ & $100 \%$ \\
\hline Fairly wet grasslands & Sandy clayey soil & $60 \%$ to $80 \%$ & $<5 \%$ & $90 \%$ to $80 \%$ \\
\hline Dry grasslands & $\begin{array}{l}\text { Sandy soil with some } \\
\text { stones on the surface }\end{array}$ & Less than $40 \%$ & More than $5 \%$ & $80 \%$ \\
\hline
\end{tabular}

formations based on hemicryptophyte and characterised by a high degree of recovery (Quézel 1957).

Oukaimeden plateau's whole flora (highly wet grasslands + pozzines, wet grasslands, fairly wet grasslands and dry grasslands) (Table 1) is characterised by a specific richness estimated at 198 species divided into 122 genus and 38 families.

The wet entity which includes highly wet grasslands + pozzines, wet grasslands, fairly wet grasslands represent a great floristic biodiversity estimated at 134 species, 97 genus and 34 families (Table 2). This represents more than $60 \%$ of the total specific richness of the Oukaimeden grasslands with a rate of endemism exceeding 25\% (29 species are endemics of Morocco only, 5 are endemics of Morocco and Iberian peninsula, 1 specie endemic of Morocco and Algeria and 1 specie endemic of Morocco, Iberian peninsula and Algeria); and degree of species rarity exceeding 20\% (15 are rare species, 8 are suspect rare species, 14 are highly rare species and 1 species is suspect highly rare) (Fig. 3). This flora extremely supplemented with plants of Euro-Siberian-Boreo-American origin (23\%) divided on 19 species of Circum-boreal origin and 13 species of Eurasiatic origin (Fig. 4), which confers to these milieus a significant floristic and landscape originality (Alaoui Haroni et al. 2005).

More specifically, these spaces are very coveted for their pastoral richness. Indeed, this study site corresponds to a collective rangeland called "Agdal:" "A traditional Institution shape of collective pastures management of the stockbreeders in the High Atlas" (Mahdi 1999). This particular traditional management of area and resources consists of limiting rights of access and (or) uses of the customary law (Ilahiane 1990; Auclair 1998), aiming to allow the milieu reconstitution in order to ensure the perenniality of the resource.

\section{Methodology}

In recent years, geographic information systems (GIS) have increasingly been used in a wide array of application contexts for development cooperation particularly in mountain areas (Heinimann et al. 2003). In this study, cartography techniques such as GIS capabilities aims to carry out dynamic map of Oukaimeden wet grasslands. This cartography required the compilation of a whole data base which included:

- Aerial photos of the 1964, 1986 and 2002 missions (Table 3).

- The satellite imagery (spot-vegetation in 2000) of the study site.

- Topographic maps digitalized and georeferenced by the software "Envi."

- The digital terrain model. 


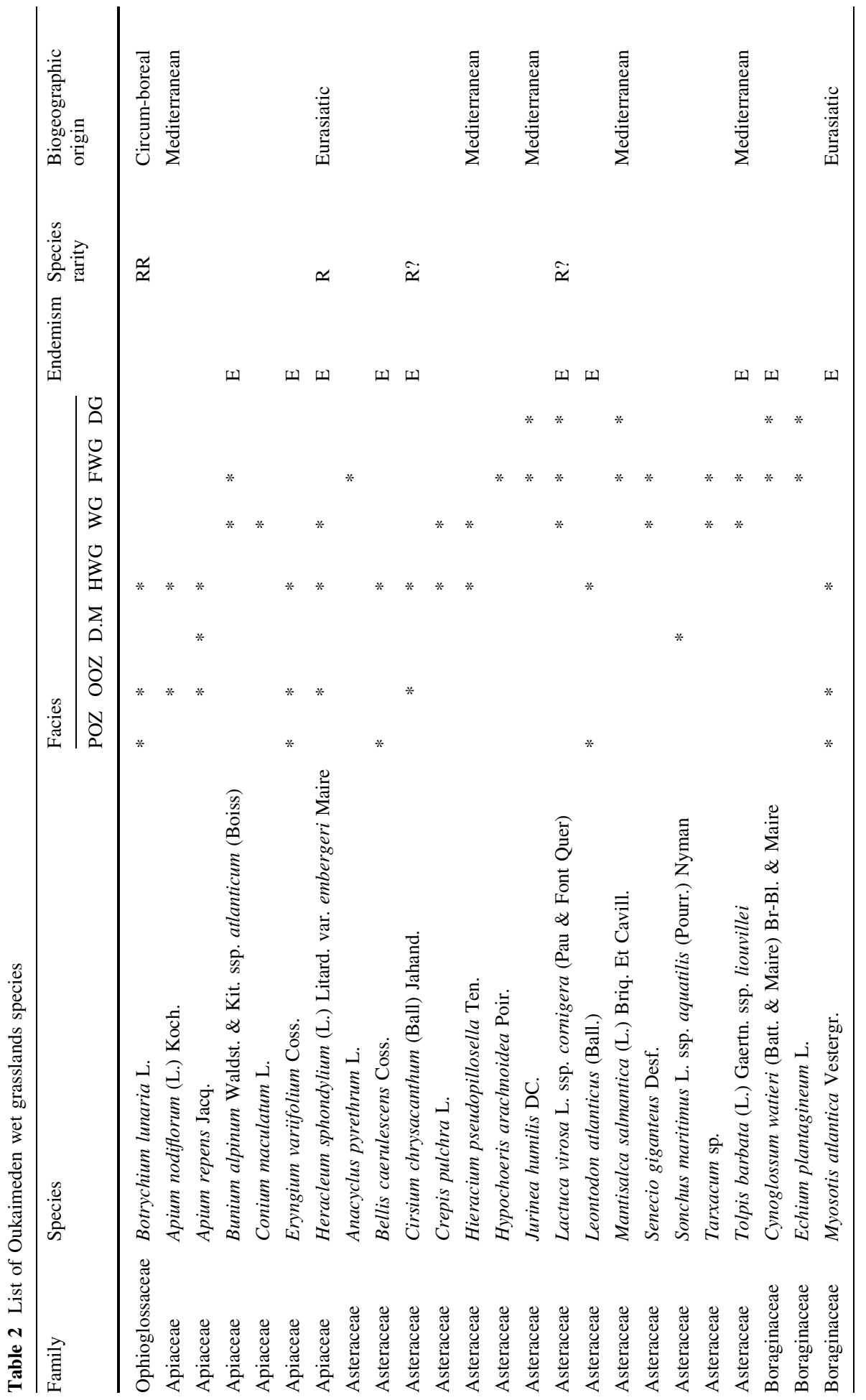




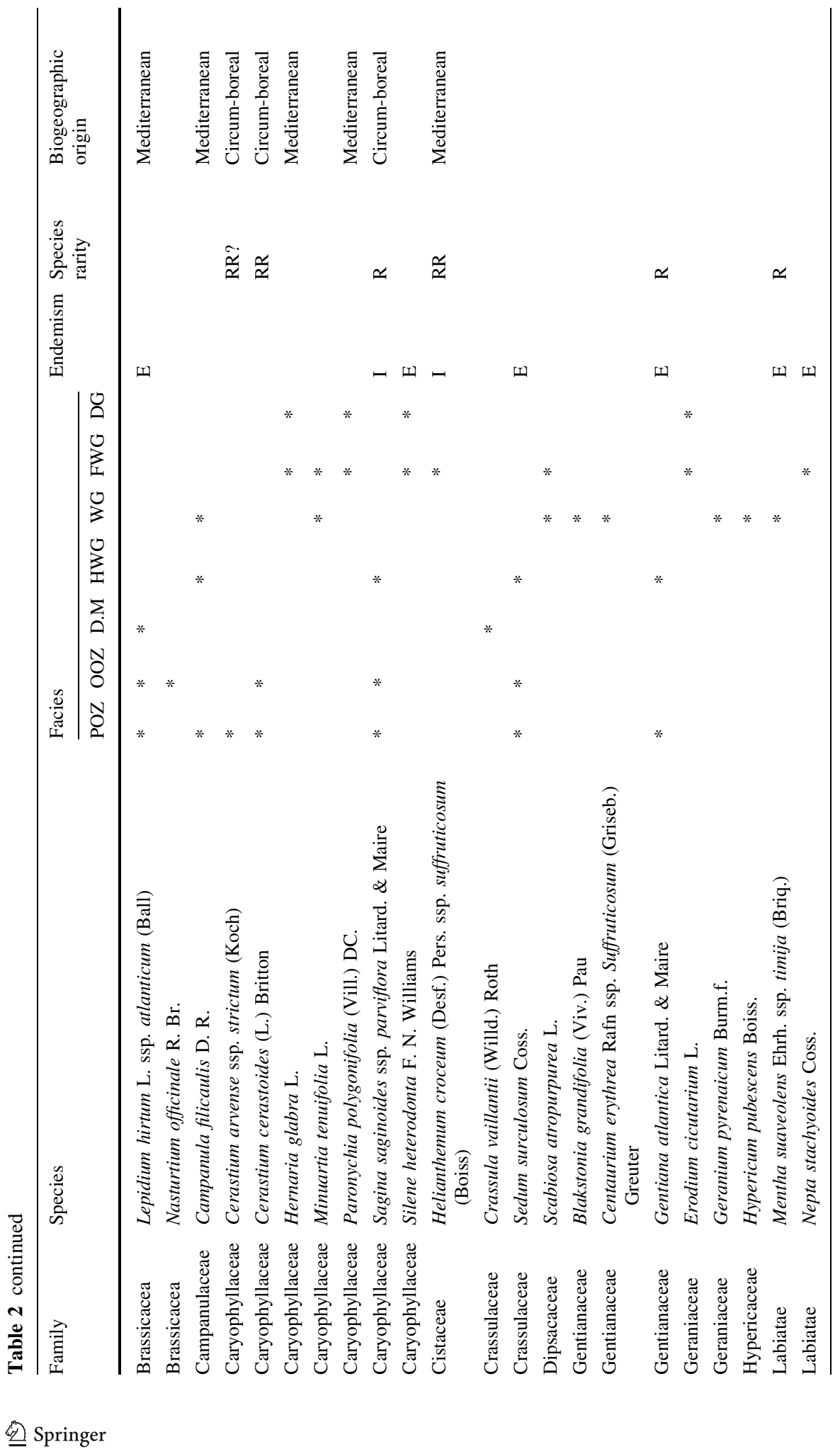




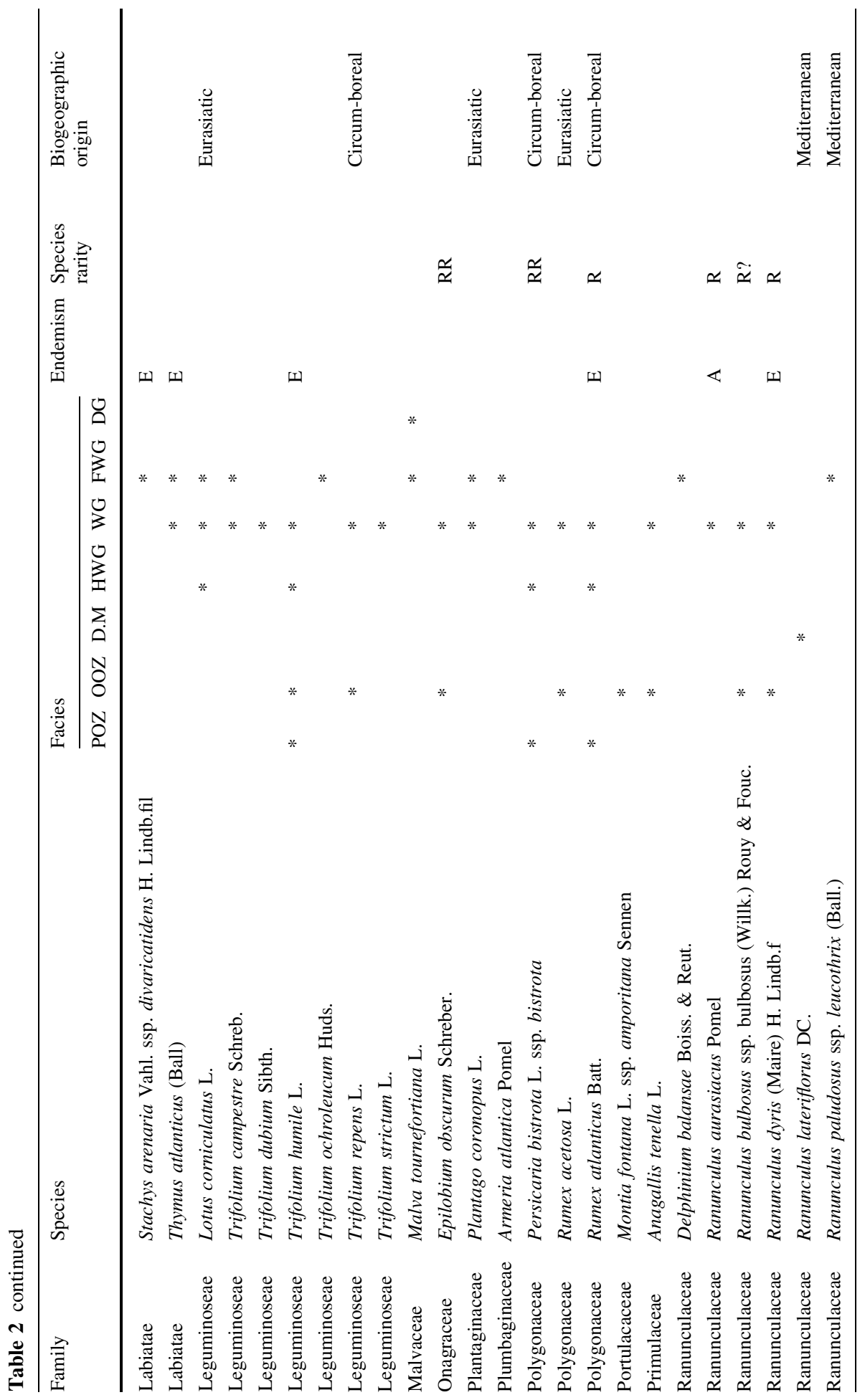




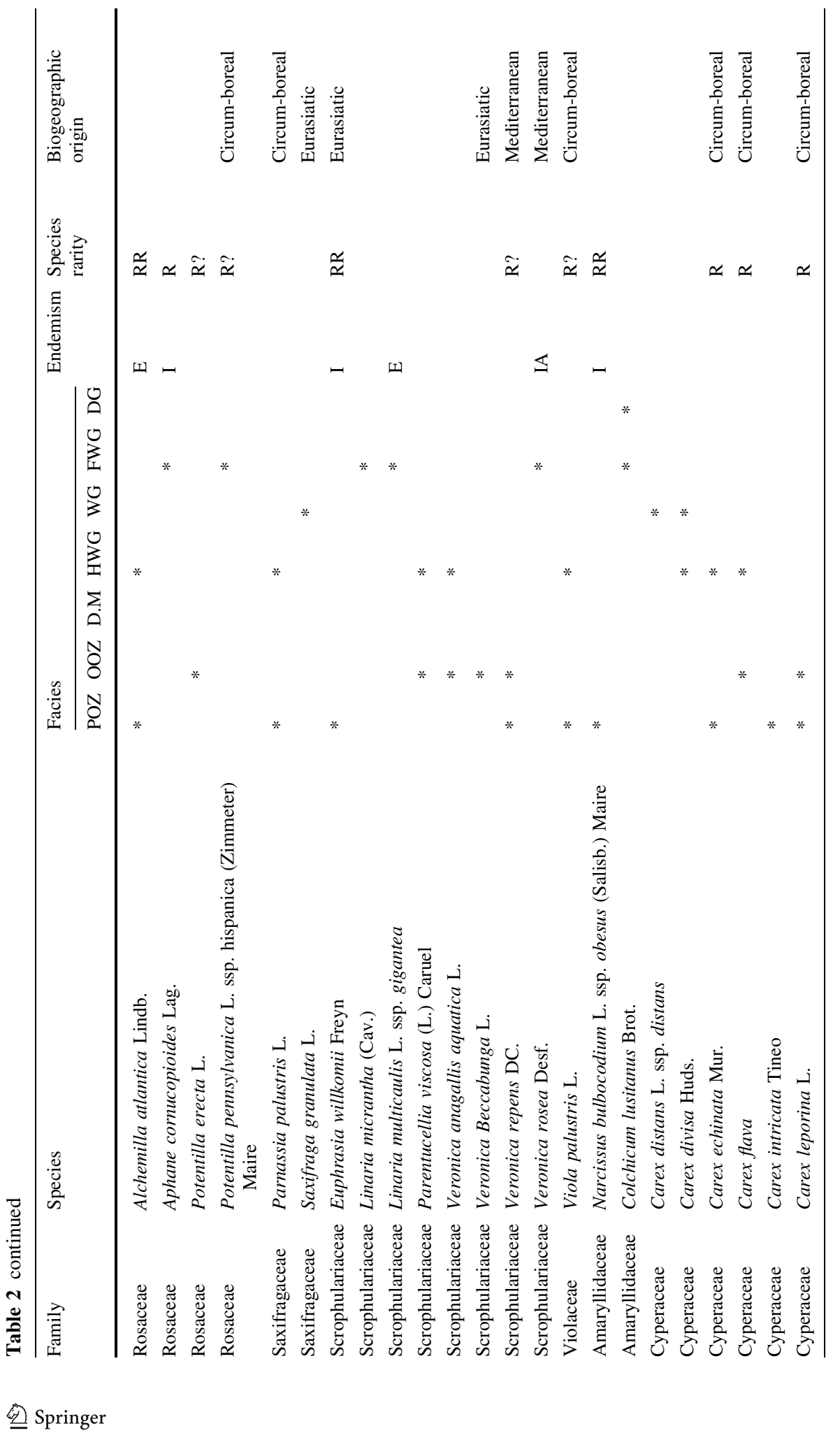




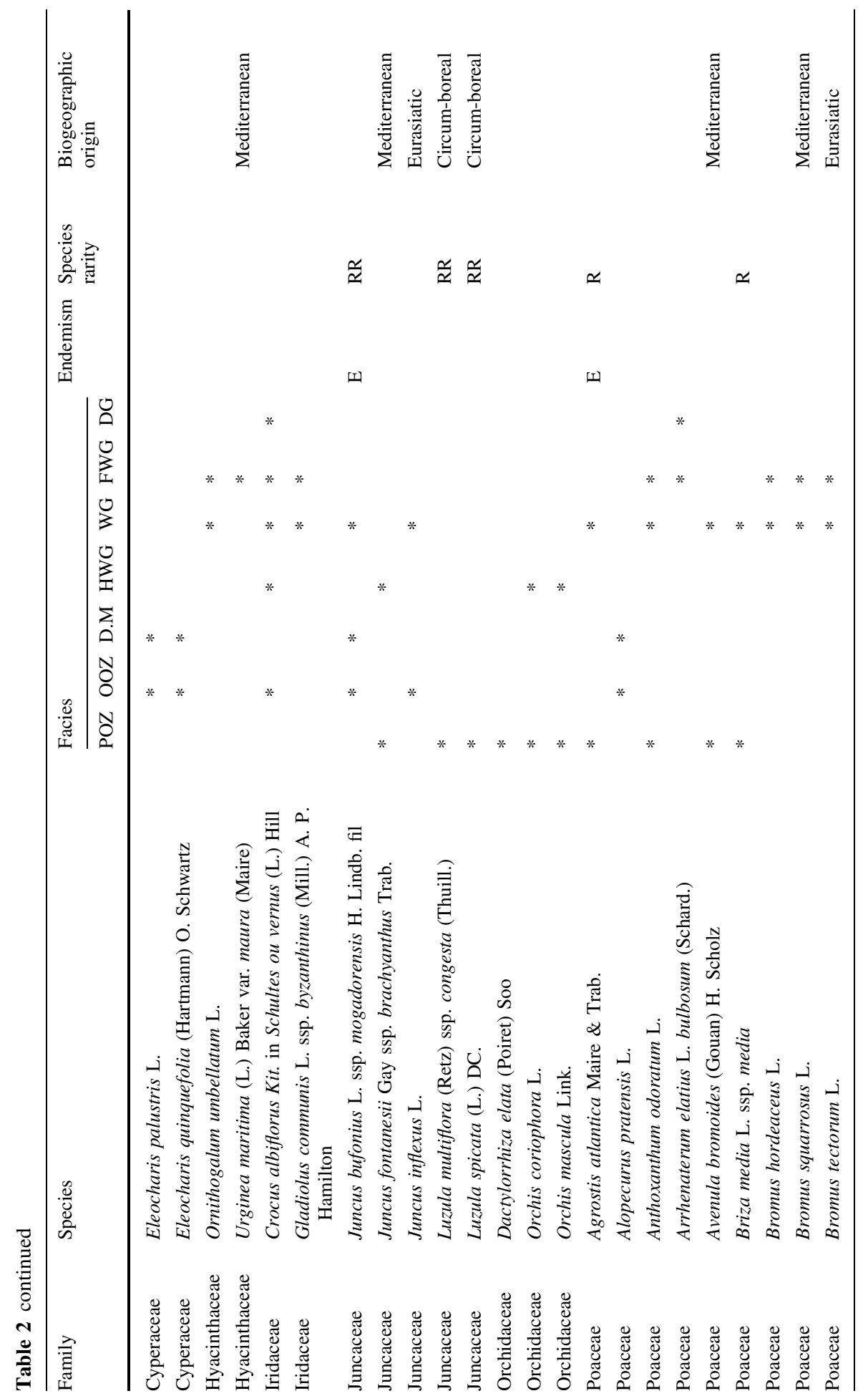




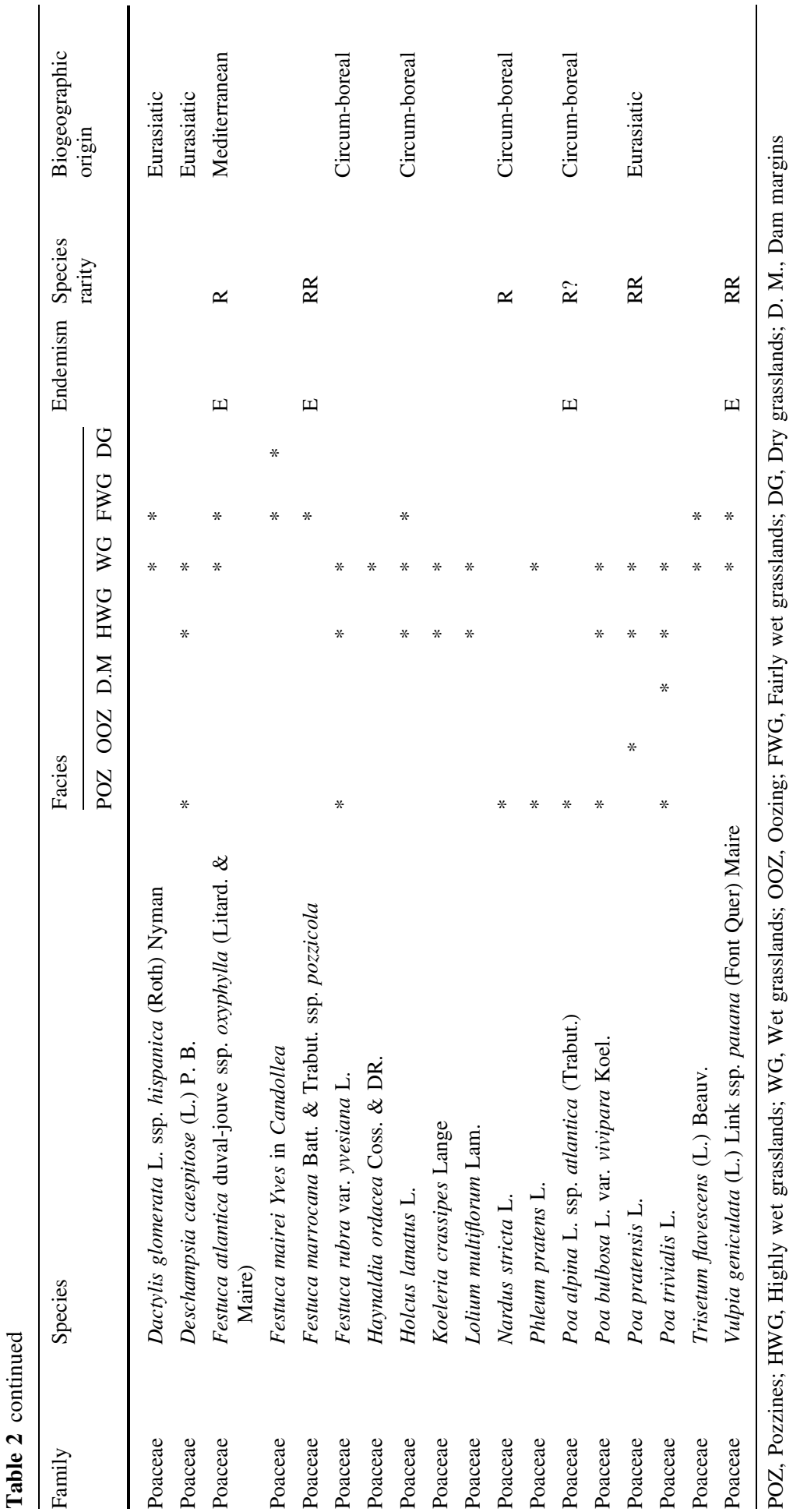




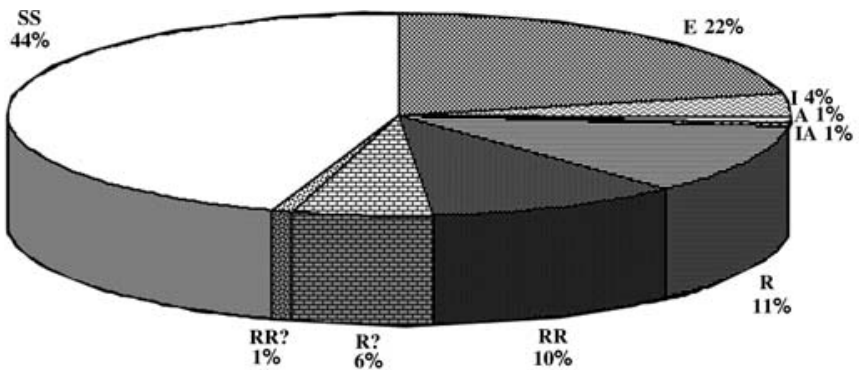

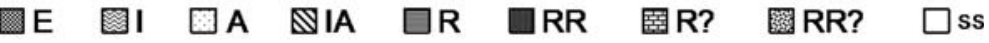

E: endemic of Morocco

I: endemic of Morocco and Iberian peninsula.

A: endemic of Morocco.

IA: endemic of Morocco, Iberian peninsula and Algeria

R : Rare specie.

R ? : Suspect rare specie

RR : Highly rare specie

RR ? : Suspect highly rare specie

SWS : Species without specific status.

Fig. 3 Status of Oukaimeden wet grasslands species. E, endemics of Morocco; I, endemics of Morocco an Iberian peninsula; A, endemic of Morocco and Algeria; IA, endemic of Morocco, Iberian Peninsula and Algeria; R, Rare species; R?, Suspect rare species; RR, Highly rare species; RR?, Suspect highly rare species; SWS, Species without specific status

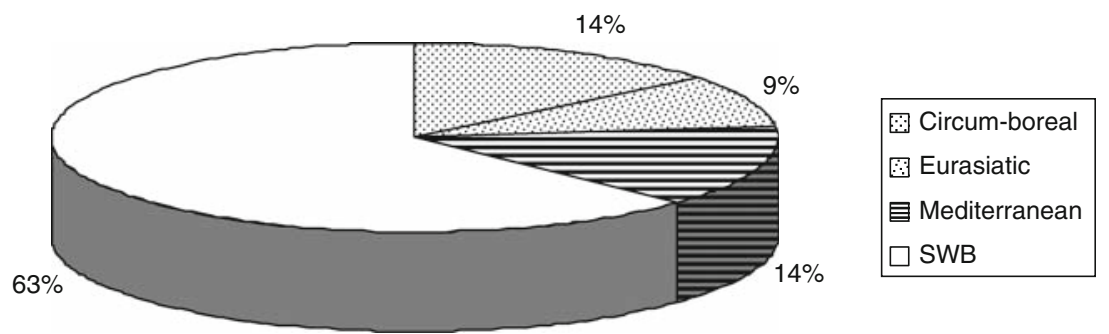

Fig. 4 Biogeographic origin of Oukaimeden wet grasslands species. SWB: species without specific biogeogaphic origin

Table 3 Characteristics of aerial photographs in used

\begin{tabular}{lllcl}
\hline Mission & Scale & Coverage & Photographs & Organism \\
\hline 1964 & $1 / 50,000$ & NH29 XXII XXIII & $185-189$ & IGN \\
1986 & $1 / 20,000$ & BD 154 & $123-127$ & IGN \\
2002 & $1 / 20,000$ & BD 05 & $05-11$ & DREF \\
& & BD 06 & $07-11$ & \\
\hline
\end{tabular}

The approach rests on two principal stages

- Pre treatment and data preparation

The various missions of the aerial photographs underwent a pre treatment by the software "Envi" which consisted of the orthorectification of these photos in order to project them 
with the GIS. The orthorectification is carried out while draw on digital terrain model and georeferenced topographic map (Toubkal 1/50,000) and satellite imagery.

- Photo-interpretation

On the aerial photos mission of 1964, 1986 and 2002 the visual photo-interpretation by stereoscope consists of delimiting homogeneous zones from the grasslands humidity point of view, which based on the distinction of the levels of gray on the photo (more the grassland is humid more it appears gray dark on the photo), the limits of the grasslands can be traced by GIS-Arcview 3.2 (Kraak et al. 1995; Wang and Ellis 2005). Thus, the updating of 2002 mission and the verification were done on the terrain via GPS points made it possible to obtain actual Oukaimeden grasslands map (2004).

The maps of 1964, 1986 and 2004 so ready will be superimposed via the GIS. The crossing between 1986 and 2004 gives rise to the dynamic map of the Oukaimeden wet grasslands and the crossing between 1964 and 1986 on only the plateau zone in the dam neighbourhoods made it possible to evaluate his contribution in the extension of the wet grasslands surfaces, we cannot carried out a whole wet grasslands evolution between 1964 and 1986 because 1964 aerial photo did not cover all the wet grasslands in the study site but only in the plateau.

\section{Results}

The monochronic cartography (Fig. 5) of Oukaimeden grasslands shows that the geomorphology and the gradient of humidity allow the individualization of the various facies (Fig. 6). This can be found from the highly wet pozzines occupants of small surfaces, to the very wide dry grasslands which mark the transition towards xeric element.

The diachronic cartography based on crossing monochromic maps 1964, 1986 and 2004 (Fig. 7, Table 4) enabled us to evaluate the spatiotemporal evolution of wet grasslands.

Between 1964 and 1986 the evolution of wet grasslands on only the plateau zone in the dam neighbourhoods made it possible to evaluate the contribution of dam construction in the extension of the wet grasslands area. So, for do it we consider various groupings of wet grasslands in 1986 as being only one wet entity.

During this period, wet grasslands knew a very significant progression. It is evaluated at 20.784 ha, the plateau grasslands areas passed from 3.24 ha at 1964 to 24.024 ha at 1986 . This progression is due to the installation of the Oukaimeden plateau dam in 1970s. This was very beneficial for the wet grasslands; it is allowed the water refill of the neighbouring soils and consequently the extension of the wet grasslands area, the dam construction allowed not only the extension of wet grasslands on the Oukaimeden plateau but also appearance of new wetlands around dam margin, indeed, wetlands in the plateau due to the dam installation are of two kinds:

- A wet grassland and pozzines that are the same as the one of origin with the same floristic content (Narcissus bulbocodium L. ssp. obesus (Salisb.) Maire, Nardus stricta L., Dactylorhiza elata (Poiret) Soo ...)

- And new wetland (Fig. 8) that never had place on the site before the dam construction; it is about flooding zone of the dam margin containing a very characteristic flora of this environment type (Crassula vaillantii (Willd.) Roth, Eleocharis palustris (L.)...), and also vegetal species that are common with the pozzines and wet grasslands (Lepidium hirtum L. ssp. atlanticum (Ball), Poa trivialis L.) (Table 5). 


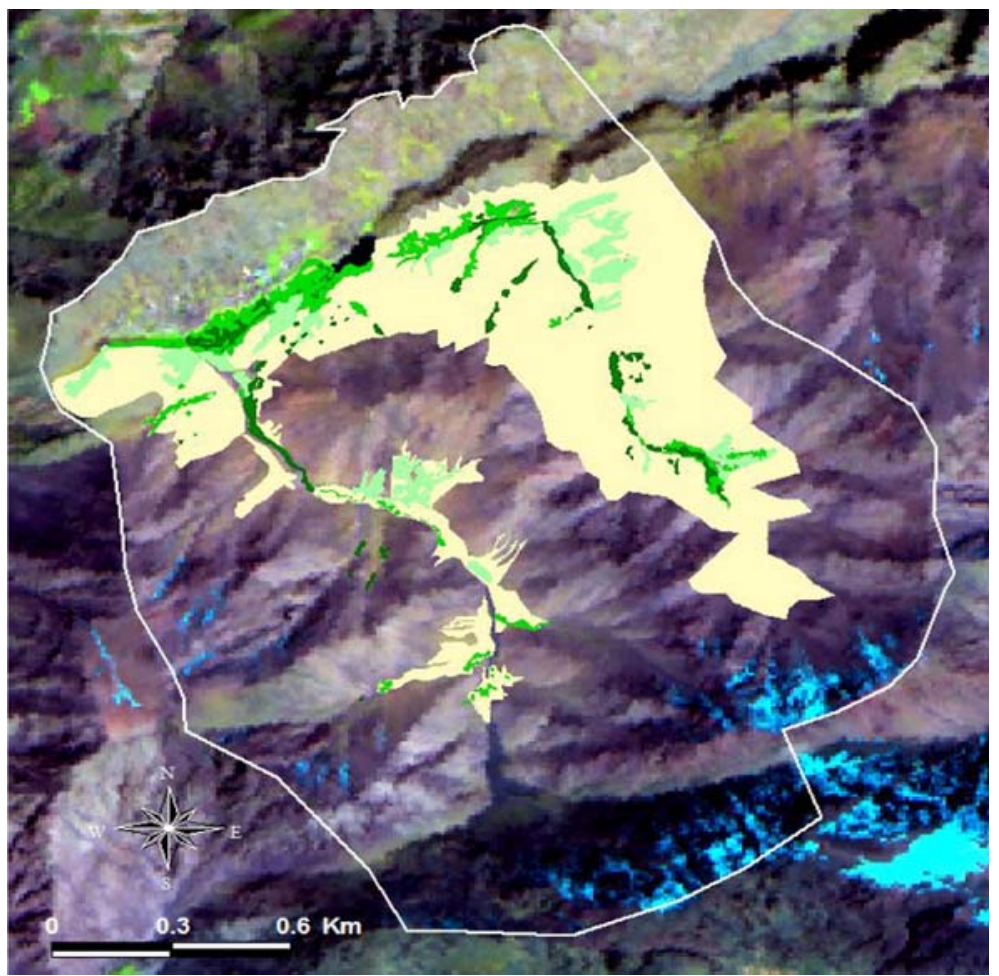

Legend:

Spatial Limits of the Agdal of Oukaimeden

Highly wet grasslands + Pozzines

$\square$ Wet grasslands

$\square$ Fairly wet grasslands

$\square$ Dry grasslands

Fig. 5 Actual cartography of Oukaimeden grasslands

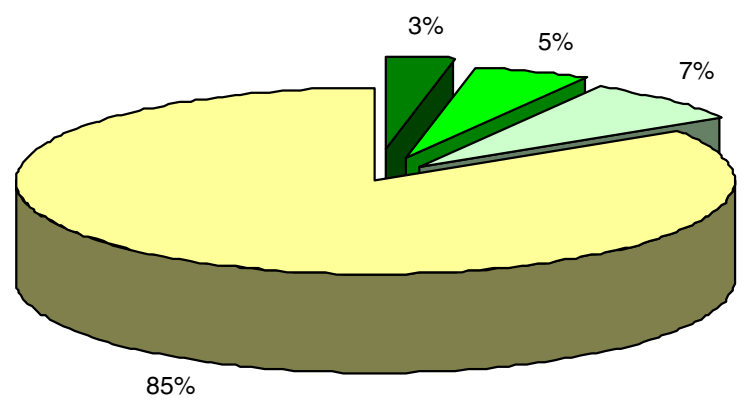

$\square$ Highly wet grasslands+Pozzines $\square$ Wet grasslands $\quad \square$ Fairly wet grasslands $\quad \square$ Dry grasslands

Fig. 6 Importance of Oukaimeden grasslands facies 
Fig. 7 Monochronic maps at 1964, 1986 and 2004
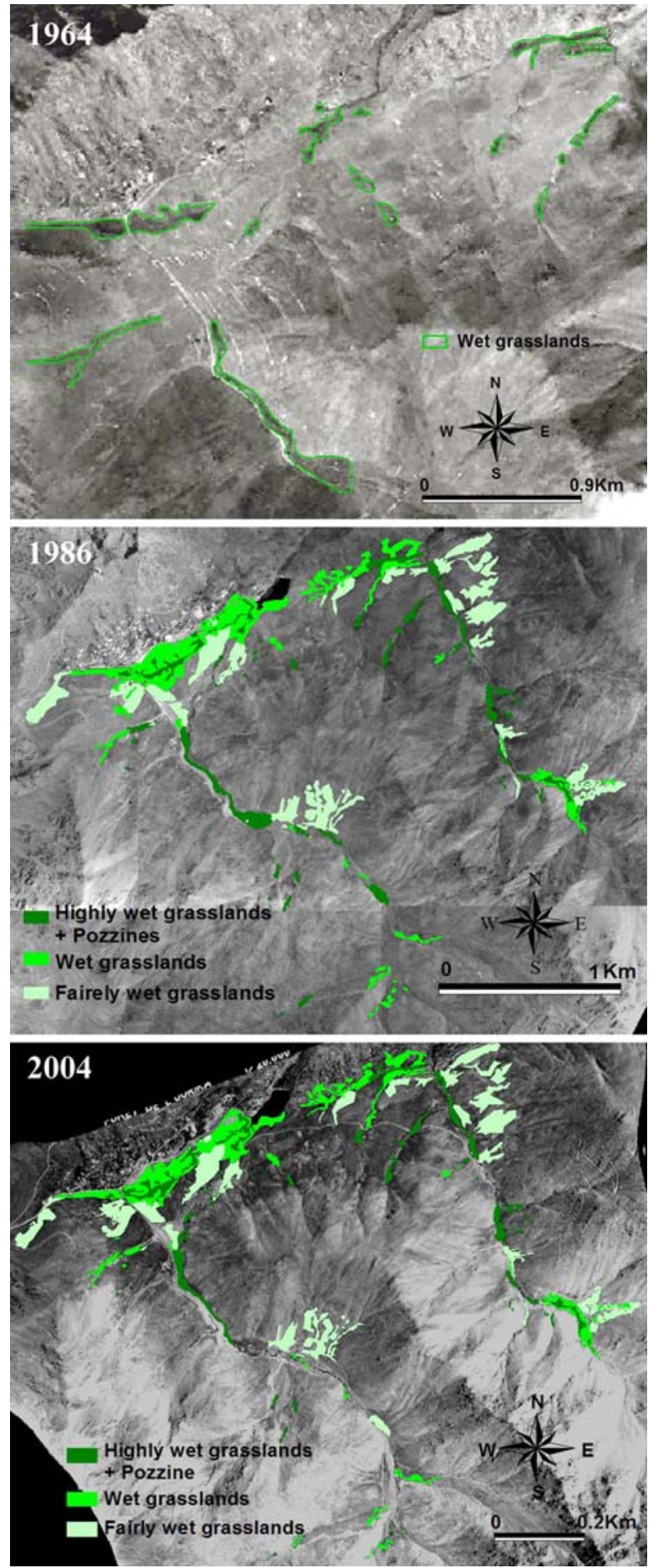
Table 4 Soil occupation between 1986 and 2004, expressed by the area at hectare

\begin{tabular}{lll}
\hline Facies of grasslands & 1986 & 2004 \\
\hline Highly wet grasslands and pozzines & 18,452 & 14,569 \\
Wet grasslands & 25,849 & 23,952 \\
Fairly wet grasslands & 34,849 & 34,120 \\
\hline
\end{tabular}

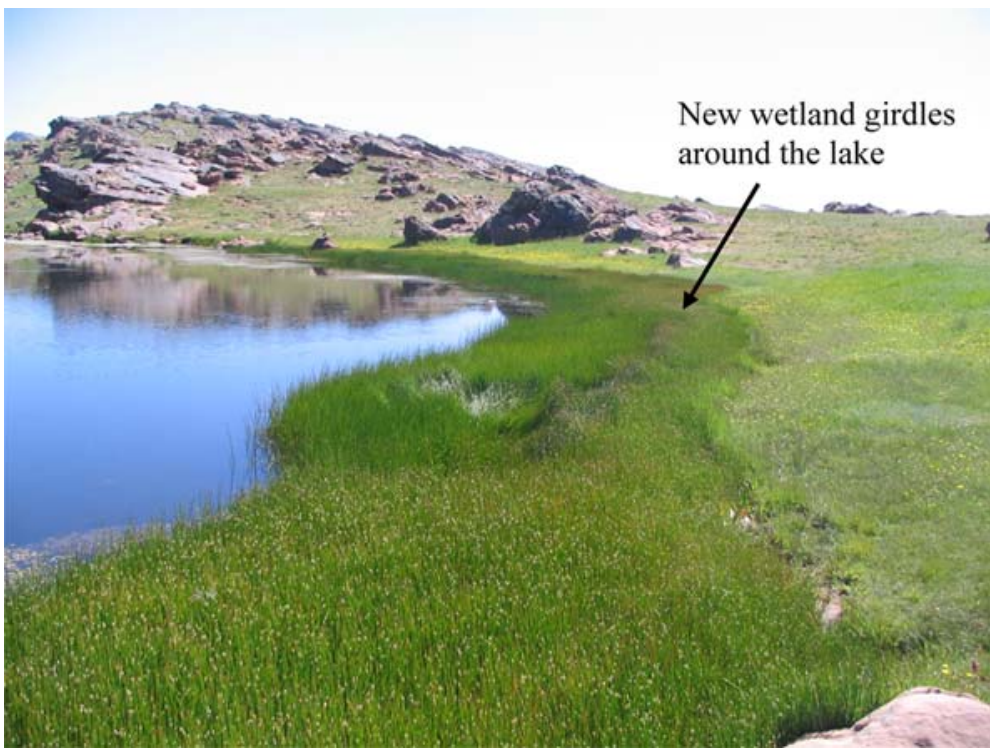

Fig. 8 New wetland created by dam construction

Pozzines's species did not colonize the new wetland yet, may be because of their mode of dissemination or because of the milieu conditions (soil nature, water retention by soil...) which do not allow the installation of these species.

Between 1986 and 2004, the dynamic map of Oukaimeden wet grasslands (Fig. 9, Table 6) translates the whole Oukaimeden wet grasslands evolution.

According to the dynamic map 8\% (6.598 ha) of Oukaimeden wet grasslands is in regression. This regression is localised in the plateau near roads and in the valleys near sheepfolder and human activities.

The regression is of two types:

Regression type 1: represents $35 \%$ and corresponds to the regressions of grasslands grouping to another grouping while remaining in the wet entity: such as the regression of the highly wet groupings to a lesser wet groupings.

Regression type 2: estimates at $65 \%$ and corresponds to the elimination of the wet entity in favour of the dry grasslands or to the total disappearance of the wet grasslands.

On the dynamic map also appears the zones which are in progression, they are estimated at 0.94 ha $(1 \%)$ and are located in the plateau near dam and along stream pouring out in the dam. 


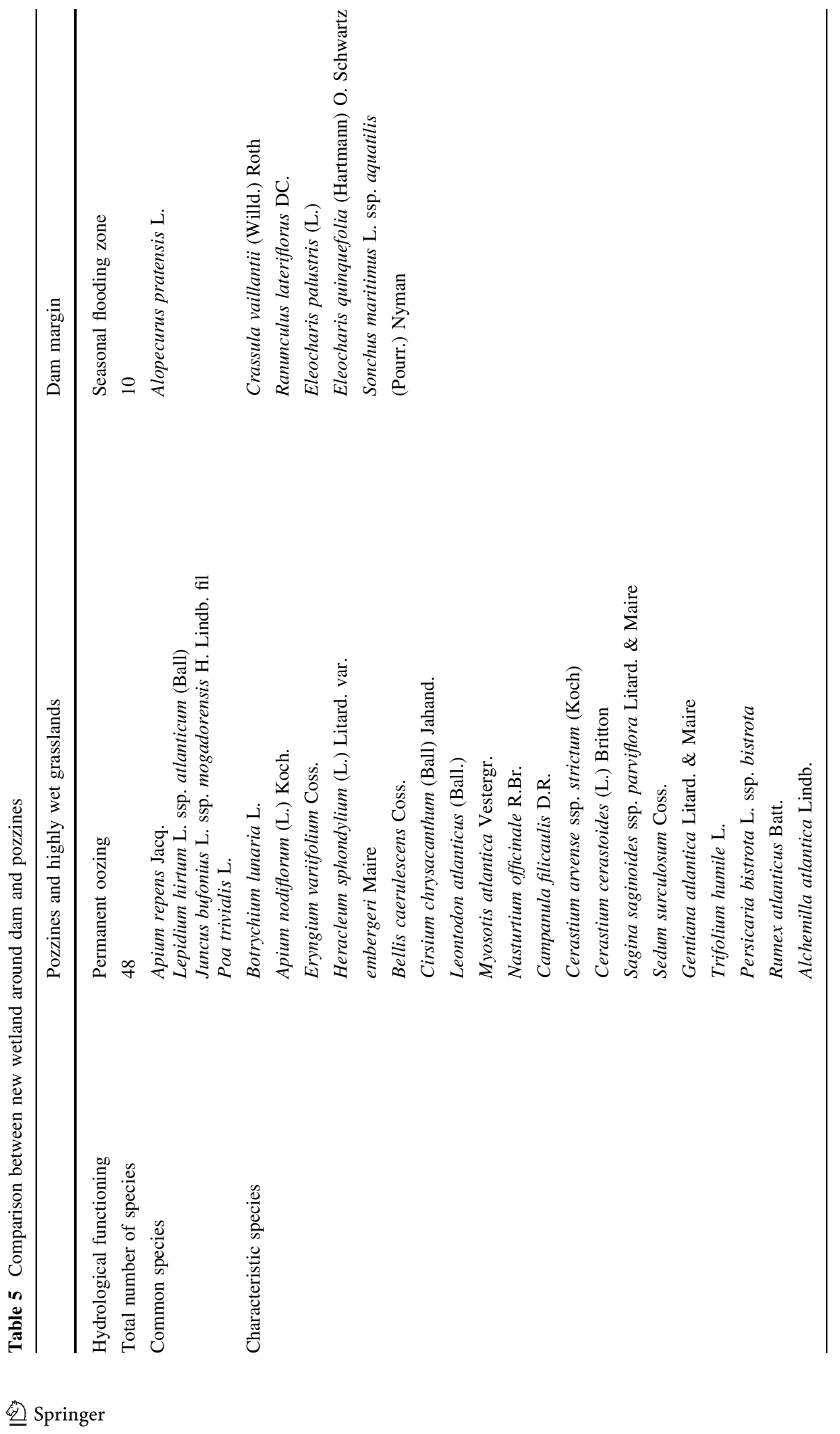




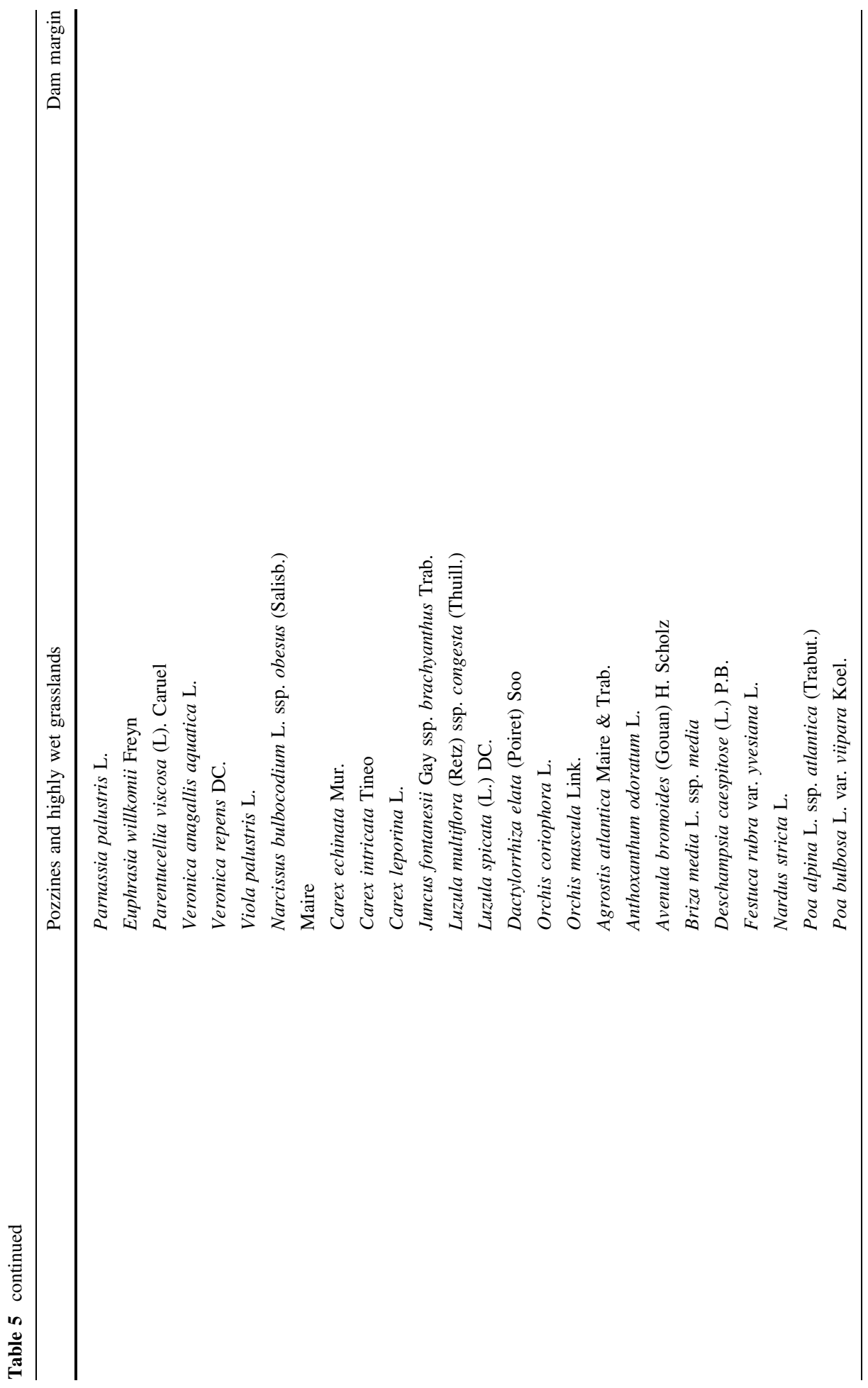




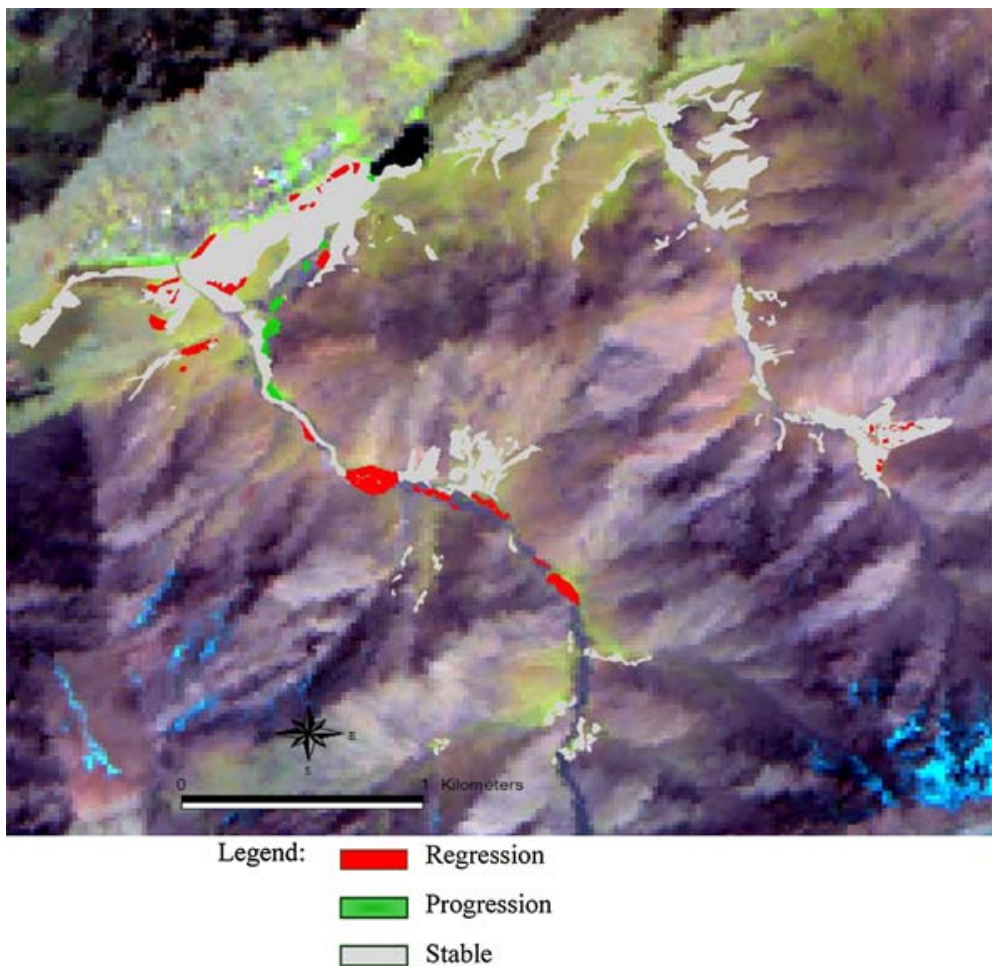

Fig. 9 Dynamic map of Oukaimeden wet grasslands

Table 6 Results of diachronic cartography of wet grasslands (between 1986 and 2004)

\begin{tabular}{lcc}
\hline Evolution type & Area (ha) & Percentage (\%) \\
\hline Progression & 940 & 1 \\
Regression & 6,598 & 8 \\
Stable & 71,612 & 91 \\
\hline
\end{tabular}

\section{Discussion}

The High mountains wet grasslands are wetlands with great ecological, economic and socio-cultural interest. These vegetal formations characterised by their significant floristic richness contain a very vulnerable flora, rich in endemic species and plants of alpine and boreal origin. The characteristic of these zones as a climatic and botanic intersection land, situated by a Mediterranean zone from the north and a strong southern influence, represents a great phytogeographical originality.

The dam installation in the 1970s was beneficial for the Oukaimeden plateau wet grasslands; it is allowed the extension of wet grasslands and the creation of new habitats for wetlands characteristic flora and fauna. Although, the spatiotemporal evolution shows some stability between 1986 and 2004 and regression representing only 8\%, the global environmental changes that the site knows all the same threaten one of the mountainous biodiversity hottest spot of Morocco and North Africa (Quézel 1957; Galland 1988). 
Because of their strict water determinism and soil, these vegetal units are very affected by the recent climatic changes which threatens our planet (Hulme 2005; Sebastià 2007).

These climatic changes, increasingly amplified by more human activity, jeopardise the rangeland productivity (particularly biomass production) and consequently ecosystem functions ( $\mathrm{Ni}$ et al. 2006). Indeed, At Oukaimeden plateau the most recent climatic changes are manifested by a considerable drop of snowfall last decades especially in spring (Fig. 10) also the Oukaimeden site knew a drop of rainfall; it was described by Quézel in 1957 in the ombrothermic diagram like a station with subhumid climate with cold winter that is the annual rainfall average between 700 and $800 \mathrm{~mm}$ but nowadays Oukaimeden is a station with semiarid climate (annual rainfall average between 400 and $500 \mathrm{~mm}$ ). These climatic changes make wet grasslands more sensitive to anthropogenic pressure.

The pastoral pressure consisting of more than 5,000 heads of livestock per year constitutes a considerable threat and causes a pressure on the natural resources (Pazos et al.
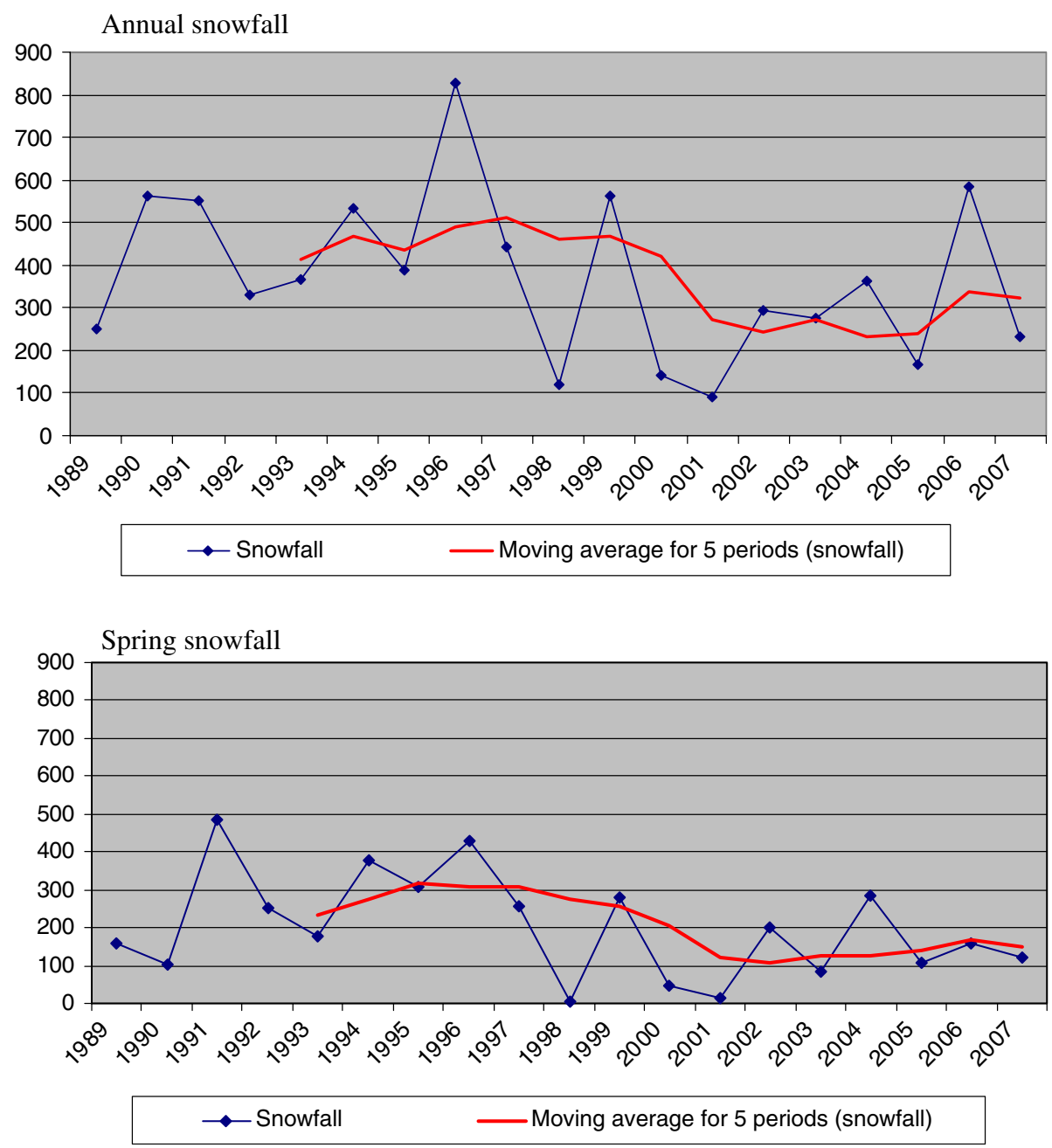

Fig. 10 Snowfall in Oukaimeden plateau between 1989 and 2007 


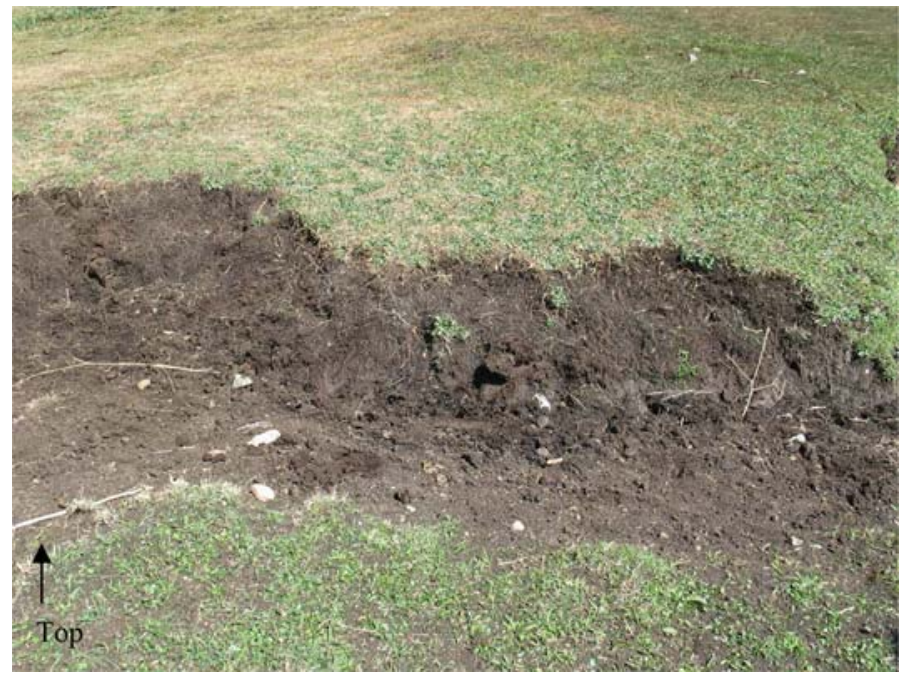

Fig. 11 The impact of livestock trampling on the wet grasslands

2007); particularly by trampling and stacking pozzines (Fig. 11) and highly wet grasslands extremely vulnerable. However and fortunately, the traditional management Agdal proves highly operational in the conservation of the vegetal biodiversity in these milieus. Indeed, this ancestral knowledge in community management of the pastoral resources access consists to the setting of temporary close of this rangeland from March 15th to August 10th (in the Oukaimeden case). The settlement of the opening and closing dates of the Agdal allows the reconstitution of the milieu by renewal of the seed stock in the ground. The opening date of the Agdal corresponds to the repercussion on the ground of seed and the

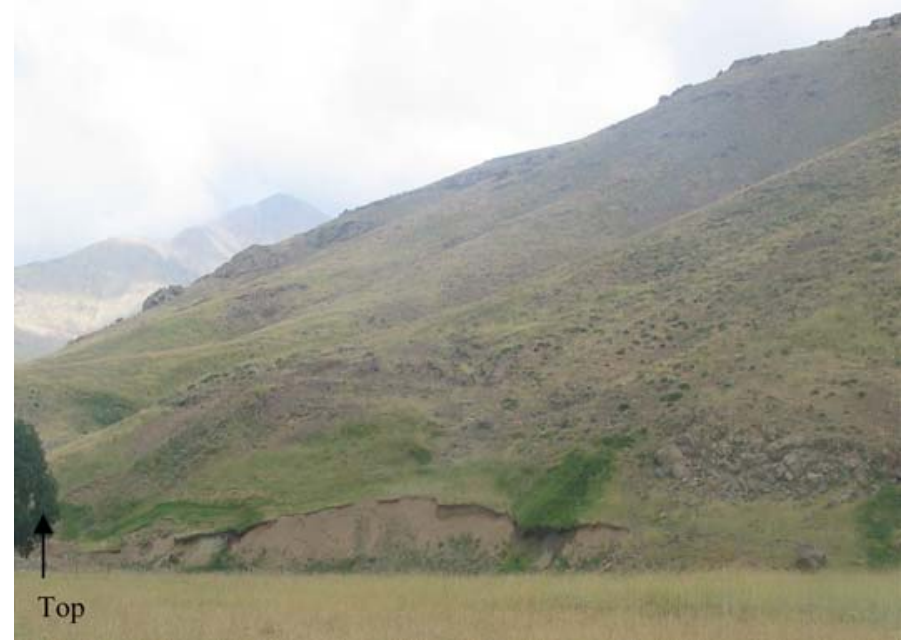

Fig. 12 Removal of soils from wet grasslands 


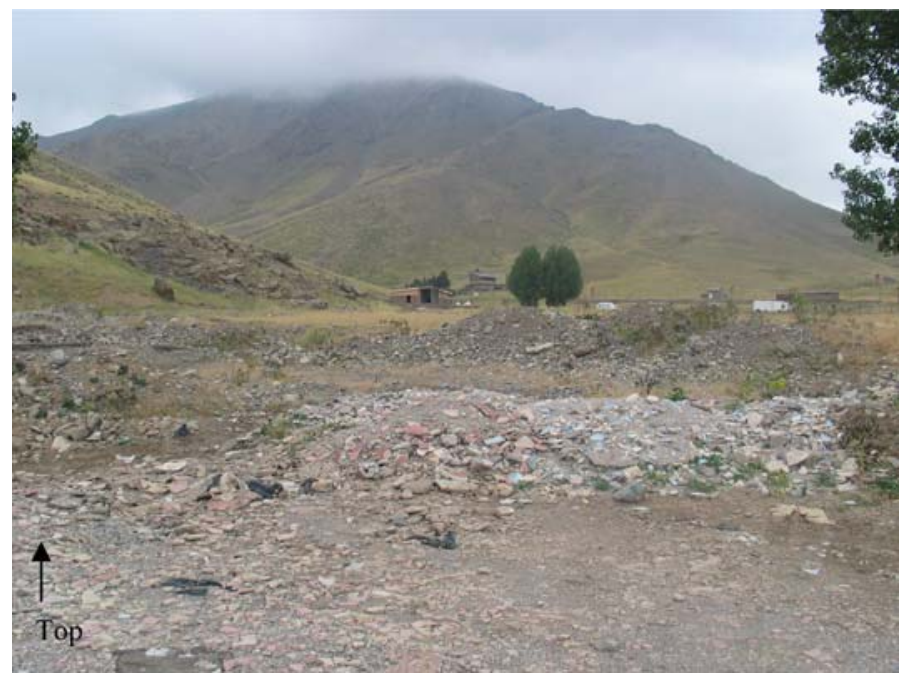

Fig. 13 Discharge on the wet grasslands

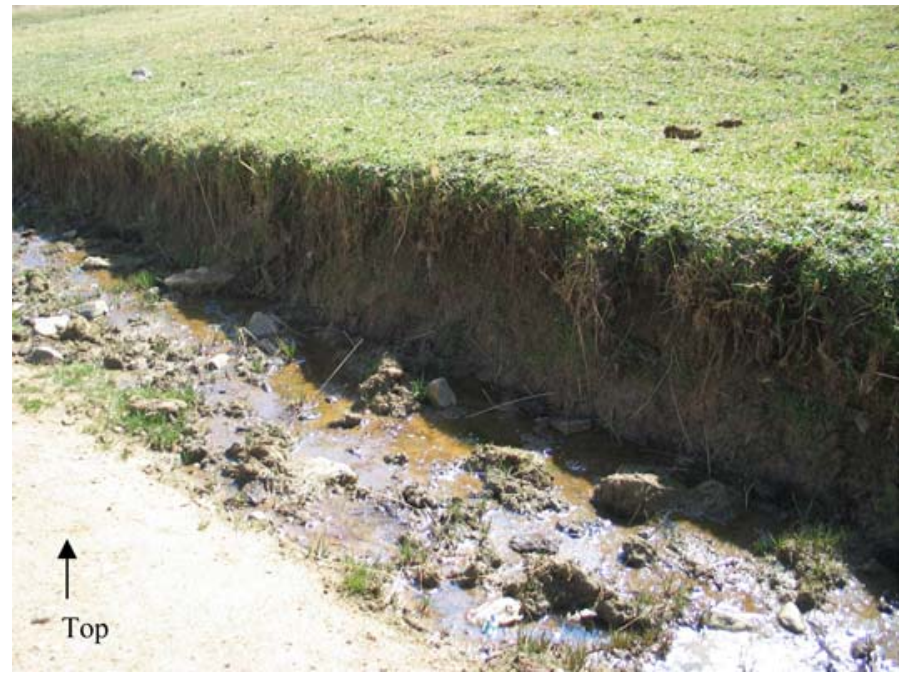

Fig. 14 Drainage pits in the wet grasslands

closure of the latest species vital cycle. The correspondence between the opening date and the resource regeneration proves the efficiency of this kind of management that aims for the milieu reconstitution and the resource safeguard.

However, the increasing promotion of the tourist activity and in particular, mountain tourism directly affects these wetlands. Indeed, Oukaimeden is a station of skiing with touristic vocation, this tourist activity requires the adjustment of various infrastructures: drain off canals of snow melting waters, rains and sewages, reception facilities: hotels, chalets, restaurants... These various adjustments of construction draw their raw materials 
(removal of soils and gravels) from extended neighbouring wet grasslands. The impact does not stop there, in addition to the building materials removal (Fig. 12); the wet grasslands also receive waste construction, turning the space into a real discharge (Fig. 13).

Furthermore, the opening of road and path in order to facilitate the moving between different "douars" (villages) in the neighbourhoods of the Oukaimeden plateau created the drainage pits (Fig. 14) that leads to the drainage of soil water reserve ending in drying up of wet grasslands. This had as consequence the extension of the dry grasslands to the detriment of the oozing wet grasslands. The original vegetal communities, characterised by a strong representation of a particular mountainous flora of Morocco, cannot support such disturbances. But, the regression that knew the Oukaimeden wet grasslands has affected these zones at the level of their superficies and areas, we did not note the disappearance of characteristic taxa even the rarest ones.

\section{Conclusion and perspective conservation}

Altitudinal wet grasslands present a very significant ecological and biological inheritance.

These wet grasslands flora is supplemented by endemic and boreo-alpine species and constitute one of the primordial natural resources that are still allowing to maintain populations in such a marginal and sensitive space. Even if these wet grasslands know some temporal stability they deserve all the same that we act as soon as for their preservation and threats protection. Thus, we propose the following means of conservation:

- The valorisation of the indigenous knowledge as well as the community management for the access to the pastorals resources (Agdal). This type of ancestral practice allows the milieu reconstitution and the conservation of these pastoral spaces. Especially, front of the failure of the nature conservation strategies in Morocco, common protected area like pastoral Agdal appear better conserved, managed by local population and having rights with a collective way guaranteeing the durability of the resource. Thus, the registration of the site as protected area according to the common laws with the establishment of green track rigorously respected can constitute a very judicious means of valorisation of this site with all these ecological components, biological and human.

- The valorisation of these wet pastures by educative tourism, by the creation in situ of school camps allowing children to develop a sense of naturalism.

- The recognition of Oukaimeden site as an important plant area (IPA) or as a site of biological and ecological interest (SIBE) (new type of protected areas in Morocco), forcing the local actors to take measures to safeguard and conserve this biological and ecological heritage.

- The scientific valorisation of the site by creating an observation center of the biodiversity evolution of the High Atlas wetlands sites, and at the same time, be able to adopt a global and comparative approach between these various wet sites.

Acknowledgements This work comes from the framework of the research program «Les Agdal du Haut Atlas marocain: biodiversité et gestion communautaire de l'accès aux espaces sylvopastoraux». Many thanks for its financial support and scientific (Convention of IRD-IFB financing/INRA N 2886). We gratefully acknowledge the SudMed project carried out by the IRD and the University Cadi Ayyad of Marrakesh and the CAF (French Alpine Club) for the logistics and climatic data that they provided us. 


\section{References}

Alaoui Haroni S, Alifriqui M, Simonneaux V (2005) Altitudinal wet pastures: threats and conservation means; the case of Oukaimeden plateau (High Atlas Mountains, morocco). In: 6th international conference, European Water Resources Association, EWRA, Palais de l'Europe, Menton, France

Auclair L (1998) Les ressources sylvopastorales au Maghreb. Structure segmentaire et appropriation communautaire. In: Sociétés rurales et environnement. G. Rossi (dir.). Karthala/GRET (éd.), Paris, pp $123-140$

Berque J (1955) Structures sociales du Haut Atlas, 2nd edn. P.U.F., Paris 513 pp

Dresch J (1941) Recherches sur l'évolution du relief dans le massif central du grand Atlas, le Haouz et le Sous. Imprimerie Arrault-Tours, pp 256-259

Galland N (1988) L'origine de la flore orophile du Maroc étude caryologique et cytogéographique; série botanique $n^{\circ} 5$ Rabat

Gauquelin T (1988) Dynamique de la végétation et des formations superficielles dans les montagnes du bassin occidental de la méditerranée: étude des formations a genévrier thurifère et xérophytes épineuses en coussinet des atlas marocains; doctorat d'état; université Paul Sabatier, Toulouse

Hammada S, Dakki M, Ibn Tattou M, Ouyahya A, Fennane M (2004) Analyse de la biodiversité floristique des zones humides du Maroc. Flore rare, menacée et halophile. Acta Botanica Malacitana 29, Malaga, pp 43-66

Harris JA, Hobbs R, J Higgs R, Aronson J (2006) Ecological restoration and global climate change. Restor Ecol 14:170-176. doi:10.1111/j.1526-100X.2006.00136.x

He C, Zhang Q, Li Y, Li X, Shi P (2005) Zoning grassland protection area using remote sensing and cellular automata modeling. A case study in Xilingol steppe grassland in northern China. J Arid Environ 63:814-826. doi:10.1016/j.jaridenv.2005.03.028

Heinimann A, Breu T, Kohler T (2003) The challenge of applying geographic information system to sustainable mountain development. Mt Res Dev 23:312-319. doi:10.1659/0276-4741(2003)023 [0312:TCOAGI]2.0.CO;2

Hulme PE (2005) Adapting to climate change: is there scope for ecological management in the face of a global threat? J Appl Ecol 42:784-794. doi:10.1111/j.1365-2664.2005.01082.x

Ilahiane H (1990) The berber Agdal institution: indigenous range management in the Atlas mountains. Ethnology 38:21-45. doi:10.2307/3774085

Kraak M-J, Müller J-C, Ormeling F (1995) GIS-cartography: visual decision support for spatio-temporal data handling. Int J Geogr Inf Sci 9:637-645. doi:10.1080/02693799508902061

Mahdi M (1999) Pasteur de l'Atlas, production pastorale, droit et rituel, lère édition

Ni J, Wang GH, Bai YF, Li XZ (2006) Scale-dependent relationships between plant diversity and aboveground biomass in temperate grasslands, south-eastern Mongolia. J Arid Environ 68:132-142. doi: 10.1016/j.jaridenv.2006.05.003

Pazos GE, Bisigato AJ, Bertiller MB (2007) Abundance and spatial patterning of coexisting perennial grasses in grazed shrublands of the Patagonian Monte. J Arid Environ 70:316-328. doi:10.1016/ j.jaridenv.2006.12.025

Quézel P (1957) Peuplement végétal des hautes montagnes de l'Afrique du nord. Encyclopédie biogéographique et écologique, édition P. Lechvalier, Paris

Sebastià MT (2007) Plant guilds drive biomass response to global warming and water availability in subalpine grassland. J Appl Ecol 44:158-167. doi:10.1111/j.1365-2664.2006.01232.x

Wang H, Ellis EC (2005) Spatial accuracy of orthorectified IKONOS imagery and historical aerial photographs across five sites in China. Int J Remote Sens 26:1893-1911. doi:10.1080/01431160 512331326684 